Timothy Josling is a professor and senior fellow at the Institute for International Studies at Stanford University. This paper was prepared before the Seattle Ministerial Meeting of the WTO. The breakdown of the talks in Seattle has changed the context in which the agricultural negotiations will take place, though not the issues that will be discussed. This change in context is discussed in a post-Seattle postscript added by the author in December 1999.

\section{The Agricultural Negotiations: An Overflowing Agenda}

\section{Timothy Josling}

T he agenda for the upcoming World Trade Organization (WTO) negotiations on agricultural trade is taking shape. Countries have begun to formulate their overall approach to the round, and to define their own expectations. Many have tabled papers in the WTO General Council outlining their positions. ${ }^{1}$ One country, Canada, has gone farther down the road, and issued a more specific statement of aims and approaches. ${ }^{2}$ In addition, over 40 papers have been prepared in the context of the "Analysis and Information Exchange" process authorized at the Singapore WTO Ministerial and conducted informally by the Committee on Agriculture. ${ }^{3}$ In other words, countries are ready to start the agricultural talks as soon as they get the green light from Seattle. This does not mean that the talks will be easy. However well-prepared the negotiators are, the prospect of stalemate or of minimal progress cannot be ruled out. This paper discusses both the substantive agenda for the talks and the frictions that are emerging as countries take their stands. It is too early to predict the outcome of the discussions, but some idea of the timetable can be inferred from the political calendar.

The next "round" of agricultural talks will be different in many respects from the Uruguay Round or its predecessors. In some ways the task of the negotiators will be more clear-cut, in large part because of the transparency introduced by the Uruguay Round Agreement on Agriculture (URAA). Tariff levels are easier to negotiate than non-tariff barriers, and the defined commitments on export subsidies and domestic support can be subject to further cuts without revisiting the definitions. But clear-cut tasks can also focus opposition. There are several countries that would prefer not to pursue the path toward a more open trade system for agriculture, or at least not be pushed in that direction by international pressure. Moreover, as always, negotiations will take place in the context of contemporary events. These events could overshadow and even derail the talks. The agenda already has been influenced by a number of issues that were not on the table during the Uruguay Round. There is no reason to believe that the agenda will stop shifting with the formal start of talks at the end of this year.

The URAA marked a turning point in agricultural trade policy. Prior to the URAA, national policies were largely unchecked by trade rules. Non-tariff barriers were the norm, implying a lack of transparency in trade and little incentive for the development of competitive exports. Export subsidies made it difficult for competitive exporters to develop markets. Domestic subsidies tilted the playing field in favor of less-efficient producers at home and limited the scale of specialization. The URAA established new rules that radically improved the agri-food trade system. Non-tariff barriers were replaced by bound tariffs. Export subsidies have been limited both in the expenditure and the quantity which can benefit from subsidies. Domestic support is now categorized as to whether it is minimally distorting (green box), linked to production controls (blue box) or output-increasing (amber box), and this last is subject to agreed limits.

The next step, already mandated in the Agreement (Article 20), is to hold further negotiations to continue the reform and market liberalization process (WTO, 1995). It is widely accepted that the Agreement on Agriculture did little to liberalize trade in agricultural products and improve market access. Tariffs on agricultural goods are still on average about three times as high as on manufactured goods and continue to distort trade. ${ }^{4}$ The

\footnotetext{
${ }^{1}$ Many of these papers are available on the WTO web site, $<$ http://www.wto.org/ $>$, though a few countries have restricted access to their position papers. If this admirable transparency continues, this will be the first set of trade negotiations where outside observers will be able to share in the progress without having to beg, borrow, or steal the papers from trade officials.

2 “Canada's Initial Negotiating Position on Agriculture," Press Release from Agriculture and Agri-Food Canada, August 19,1999.

${ }^{3}$ Unfortunately, the objections of one country have prevented these useful documents from being made publicly available.

${ }^{4}$ The gap for industrial countries is even greater, where the ratio of agricultural to industrial tariffs is closer to 10-to- 1 .
} 
process of "tariffication" has produced a number of tariffs bound at such high levels that it is difficult to see how they could be reduced by conventional tariff-reduction techniques. Where tariff rate quotas (TRQs) were negotiated to pry open these markets a little, the prospect of quota rents has led governments to agree to a network of bilateral deals, and firms to become concerned with market shares. This has, in turn, exacerbated the problem of competition between state trading enterprises and the private trade. Export subsidies still exist, and are in effect legitimized to the extent of their incorporation in country schedules. The domestic farm policies of the major industrial countries have been required to make only relatively minor changes to bring them into conformity with the Agreement.

In addition to the Agreement on Agriculture, countries negotiated in the Uruguay Round an Agreement on Sanitary and Phytosanitary Standards (SPS Agreement), which was aimed at the misuse of regulations guarding animal, plant, and human health for purposes of protecting the incomes of local producers. By requiring scientific justification for standards higher than those agreed by international bodies, the SPS Agreement has had the effect of encouraging countries to re-examine their practices in this area. But even in this area there are issues that remain to be clarified before trade can flow unhampered by questionable health barriers. Though there is no requirement to negotiate changes in the SPS Agreement, some countries have indicated that they wish to see modifications.

The overall objective of the next round of agricultural talks clearly will be to continue the progress made at the Uruguay Round. This implies negotiations on improved market access, further constraints on export subsidies and, if exporters get their way, some tightening of the rules for domestic support. But if this is the core agenda, there are a number of other issues that have emerged as a result of the experience with the Uruguay Round Agreement that can be thought of as "extensions" of the URAA core agenda, such as the administration of TRQs and the issues of state trading and of export restrictions. As if this was not enough, several other items are clamoring for a place on the agenda. This paper attempts to identify some of these other "new" issues and relate them to the core items of the agenda. Some of these issues will be dealt with in parallel to the agricultural talks, though not necessarily by the same committee, and will be part of whatever package emerges. These parallel topics include the sensitive questions of health and food safety along with a number of environmental issues relating to agriculture and biotechnology. Also important to agriculture are the issues of regional trade agreements and preferential trade arrangements.

In addition, agriculture could be impacted by talks in seemingly unrelated areas if they prove to be a part of the negotiations. These include the review of intellectual property rules, as well as those on competition and investment. As always, there are a number of political factors that will condition the pace of the talks, including the changing power relationship between the Parliament and the Commission in the European Union; the lack of "fast track" trade negotiating authority in the United States; the imminent accession of China to the WTO; and the newly emerging determination of developing countries to be full partners in the WTO. One should also not forget the impact of the state of commodity markets, which can have a marked effect on the progress of agricultural talks as it impinges on the perceptions and policies of individual countries. Each of these could have a significant bearing on the agricultural talks, and are mentioned briefly below.

\section{THE CORE AGRICULTURAL AGENDA}

The new round of agricultural negotiations will in all probability be launched at the Seattle Ministerial. As a key part of the so-called "built-in agenda," the commitment to begin talks before the end of 1999 has already been taken. Whether or not these agricultural talks are part of a major round has yet to be decided. Though this may influence the speed and scope of the talks, the "core" agricultural agenda is largely set. This core agenda will follow closely in the steps of the URAA. The triad of "market access," "export competition," and "domestic support" seems to have proved a convenient set of labels for defining current obligations, and all papers relating to the agricultural agenda use this categorization of issues.

\section{Expanding Market Access}

The market access negotiations will be at the heart of the next agricultural round. The talks will not be a success unless a substantial step is taken to reduce the high levels of agricultural tariffs. With varying degrees of enthusiasm, countries have endorsed this objective. The United States has called 
for an "ambitious" target for expansion of market access: The European Union admits that its export interests would be served by an opening of markets, but cautions that the process will take time. ${ }^{5}$ For the Cairns Group, the negotiations "must result in deep cuts to all tariffs, tariff peaks and tariff escalation." 6 Of the major players, Japan is naturally the most reticent, contributing the observation that current tariff levels "reflect particular domestic situations" and that these circumstances should be given due consideration in the negotiations. ${ }^{7}$ Developing countries tend to stress the importance of expanding market access in the products of export interest to themselves. ${ }^{8}$ In one case, a developing country argues that trade liberalization may be inappropriate for countries with foreign exchange shortages. ${ }^{9}$

From the viewpoint of improvements in the trade system, the major market access question for the next round is how can one initiate a process that would lead to a removal of the discrepancy between the level of protection in agriculture and that in the manufacturing sector in a reasonable time period? How does one get from tariffs of 100-200 or even 300 percent to the levels of 5-15 percent found in most other areas of trade? This looks to be a tall order: It implies a continued period of significant tariff cuts extending well into the next millennium.

The techniques of negotiating tariff reductions are well-established. ${ }^{10}$ One can chose between across-the-board tariff cuts or formulae that cut tariff peaks. One can focus on individual sectors (zero-for-zero arrangements) or agree on comprehensive coverage. One can use the "request and offer" method for identifying demands for market access, multilateralizing the results. One can attempt to reduce effective protection by making sure that processed-good tariffs come down at the same rate or faster than those of raw materials. It is unlikely that the ministers meeting in Seattle can agree on the modalities, though one would expect them to specify the broad parameters.

The methods of market access discussed above each have some merit but might not be adequate in themselves. This suggests that negotiators might try a "cocktail" of the various modalities. ${ }^{11}$ Imagine agricultural tariffs divided into five categories. Low tariffs, those less than 5 percent, could be reduced to zero, as neither the level of protection nor the revenue collected are likely to be significant. Such nuisance tariffs could be removed with advantage, in agriculture as well as in other areas. Moderate tariffs, of 5-40 percent, could be reduced by a further
36 percent cut, as in the Uruguay Round, or by the same percentage as other tariffs if part of a more general negotiation. The tariffs above 40 percent are probably too high to yield to the same techniques as industrial tariffs: A combination of tariff cuts and TRQ increases may be needed. Thus, for tariffs between 40 and 100 percent, the 36 percent cut could be augmented by an expansion of TRQs. For the tariffs above 100 percent, some variant of the Swiss formula may be needed along with expansion of TRQs. And for those tariffs that are above 300 percent, it may make more sense to conduct particular "request and offer" negotiations with principle (potential) suppliers.

In addition to the task of tariff level reduction, two other aspects of tariff rules will probably be discussed. One is the common phenomenon of bound rates of tariff that are considerably higher than the applied rates. ${ }^{12}$ There have been suggestions that these gaps be reduced, for instance by binding the applied rates. But this causes understandable problems for the countries involved, who will argue that the applied rates have not been negotiated in the WTO and therefore to bind these rates would be unfair to those who have undertaken unilateral liberalization. On the other hand, for those countries with such gaps, reducing the bound rate toward the

\footnotetext{
${ }^{5}$ The U.S. position is contained in documents WT/GC/W/107, 115, 286, 287, 288, and 290. The EU paper is WT/GC/W/273. The EU paper con tains the intriguing statement that it should "pursue an active market access policy with a view to eliminating barriers to entry in certain third country markets."

${ }^{6}$ See the Cairns Group "Vision" statement transmitted to the WTO as WT/L/263, and the subsequent communique from the Buenos Aires meeting of the Cairns Group, WT/L/312. The Cairns Group members are Argentina, Australia, Brazil, Canada, Chile, Colombia, Fiji, Indonesia, New Zealand, Paraguay, Philippines, South Africa, Thailand, and Uruguay.

${ }^{7}$ The Japanese paper is document WT/GC/W/220.

${ }^{8}$ See for instance, the paper by the Dominican Republic and Honduras (WT/GC/W/119).

${ }^{9}$ The papers by Pakistan (WT/GC/W/131 and 161) comment that for developing countries that are chronically short of foreign exchange, "it may be appropriate to grow their own food, as far as possible, even if it is more costly than the food stuff available in some other countries." This can either be seen as a sophisticated argument based on the theory of the second best, or a throwback to the 1960s economic policies of attempting to correct macro distortions (exchange rate imbalances) through micro actions (protecting agriculture). Or perhaps it is just a sop from the trade ministry to the agricultural ministry.

${ }^{10}$ For a discussion of tariff reduction options, see Josling and Rae (1999).

${ }^{11}$ See Josling and Rae (1999) for an elaboration of this technique.

${ }^{12}$ The U.S. paper specifically mentions the "lowering of bound rates to eliminate the disparity between applied and bound rates."
} 
applied rate is a way of getting "credit" for actions already taken.

The other aspect of tariff policy is the form of the tariff. The URAA mandated a tariff-only regime, but allowed some countries to concoct complex tariffs that involve reference prices and compound rates. ${ }^{13}$ Moreover, the Blair House agreement between the United States and the European Union obliged the European Union to impose a maximum duty-paid price for cereals that acts very much like the variable levies that were outlawed in the agreement. Many countries also would like to insist on the use of $a d$ valorem tariffs rather than specific duties, which have a somewhat more protective impact when prices are low. The United States is calling for a simplification of complex tariffs: Whether any country will take aim at de facto variable levies and specific tariffs is not so clear.

One direct way to tackle the problem of the high levels of tariffs resulting from tariffication is to expand the guaranteed market access that forms a part of the provisions of the Agreement on Agriculture. ${ }^{14}$ Some position papers (though not that of the United States) mention the importance of expanding TRQs in the next round. The Cairns Group paper says that "trade volumes under tariff rate quotas must be increased substantially." Other countries suggest further improvements in the TRQ system, in addition to the administration of the quotas (discussed in a subsequent section). Canada argues for the elimination of the withinquota tariff whenever the above quota tariff is prohibitive (presumably to ensure that the quotas are filled, rather than merely increasing quota rents at the expense of government revenue). The same paper suggests the introduction of a TRQ whenever tariffs are higher than a specified level, and increasing the product specificity of TRQs.

A possible outcome of the negotiations might be to continue the process of expanding minimum access as a proportion of consumption. An increase in TRQs, say, of 1 percent of the level of domestic consumption in each year over a five-year period would remove much of their restrictive effect. In most markets the quotas would become non-binding before the five-year period was over. In effect, tariffication would have taken place at the level of the reduced tariff applicable to the TRQ. The main political objection to this could be that the "withinquota" tariffs were generally left to the discretion of the importing country to fix at levels that they judged would attract the guaranteed access quantity.
This implies that some form of re-negotiation might have to take place on the level of these tariffs. ${ }^{15}$

Among the other market access issues, the Special Safeguard (SSG) system is also in need of some patching and more uniformity. The United States would like to see use of the SSGs further limited. ${ }^{16}$ But trade safeguards are generally considered by importing governments to be a necessary concomitant to trade liberalization and market access. The European Union has indicated that it would like to see a "renewal" of the SSG in the next agreement. Japan makes the point even more strongly, that "the current agreement acknowledges that the Special Safeguard can be maintained as long as the reform process continues." 17

One simple way to avoid the misuse of the Special Safeguard Provisions is to seek agreement on the level of trigger prices. Trigger prices could, for instance, be identical (or equivalent) to the external prices used by the governments concerned in calculating initial tariff equivalents in the UR. Governments had a tendency to use the lowest feasible external prices for calculating tariff equivalents in their Uruguay Round schedules. Hence,

\footnotetext{
${ }^{13}$ The EU tariff schedule for fruits and vegetables includes tariffs conditional on whether the offer price is below or above a reference price (International Agricultural Trade Research Consortium, 1997).

${ }^{14}$ The TRQ system is a major concern for the health of the agricultural trade system. A total of 1,366 tariff rate quotas were notified to the WTO Secretariat under the reporting requirements of the Uruguay Round. Such arrangements are particularly common in the markets for fruits and vegetables (350), meat products (249), cereals (215), dairy products (183) and oilseed products (124). Thirty-six countries undertook such commitments in their Uruguay Round schedules. Among those administering the greatest number of such quotas are Norway (232), Poland (109), Iceland (90) and the European Union (85). One worrying feature of the TRQ system is the degree of "underfill" of the quotas. The simple average quota "fill" for the years 1995 and 1996 was 64 percent and 63 percent, respectively, suggesting that the allocation mechanism is not yet adequate, that parastatals are effectively keeping imports out or that within-quota tariffs are too high to allow imports to compete. Though one can still argue that the TRQs are in most cases an improvement on the non-tariff barriers that were in place before the Round, they pose a potential threat to the further liberalization of trade.

${ }^{15}$ This, of course, also offers a possibility to start such tariffs for withinquota trade at a reasonable level in relation to other goods. All "within-quota" tariffs could be bound at (say) 20 percent, and not reduced until they became the operative tariff for the bulk of agricultural trade.

${ }^{16}$ The (second) Pakistan paper (WT/GC/W/161) argues for "elimination of the special safeguard provisions (since these are often used as protectionist tools)."

${ }^{17}$ An additional issue that is likely to arise with respect to agricultural safeguards in the agenda for the next round is the use of the Special Safeguard Provisions by developed countries to try to maintain protection against imports.
} 
using the same prices as trigger prices for the Safeguard Provisions would make sure that additional duties are not used too often, and are not set too high. It will also be important to phase out the use of the Special Safeguard Provisions after the second period of transition. This could be done by gradually adjusting the percentages in both the quantity trigger provision and the price trigger provision year by year so that the safeguards are less and less likely to cut in.

\section{Curbing Export Subsidies}

If the high level of protection sets agriculture apart, the widespread use of export subsidies is perhaps the most disruptive element in the operation of world markets. The practice of subsidizing exports of agricultural products has been constrained by the Uruguay Round, but most of the subsidies are allowed to continue in a reduced form. Countries that import agricultural products have been the gainers in economic terms from the subsidies, but even among these countries the disturbance of the domestic market has often caused problems. In the next round of negotiations, it will be more difficult than ever to persuade countries that export agricultural goods with little or no subsidy to allow countries, such as the European Union and the United States, to continue their market-distorting practices.

A further push to rein in these subsidies is high on the agenda of the Cairns Group, apparently supported by the United States. The Cairns Group paper declares that "there is no justification for maintaining export subsidies." The United States says that members "should agree to pursue an outcome that will result in an elimination of all remaining export subsidies." Canada adds that export subsidies in agriculture should be eliminated "as quickly as possible." Developing countries also are generally in favor of the elimination of export subsidies. ${ }^{18}$ Only the European Union would have great difficulty in agreeing to the dismantlement of export subsidies, though it will come under considerable pressure to do so. ${ }^{19}$

The simplest way to continue the process of reducing the incidence of export subsidies would be to extend the schedule of reductions agreed to in the Uruguay Round. As with the market access improvement, this could be done using the same base. This would imply constraining the expenditure on such subsidies by another 36 percent, thus removing 72 percent of the subsidy expenditure that was used in the base period. Continuing the quantity restriction would imply that 40 percent of the volume of subsidized exports would have been removed from the market over the two periods of reform. But since the remaining 60 percent would have to be subsidized with only 29 percent of the expenditure, the disruption that could be caused by such subsidies would be significantly reduced.

The continuation of the process of reduction would be constructive, but elimination of export subsidies altogether would clearly have significant advantages. But the prerequisites for dispensing with export subsidies are a renewed confidence in world markets, with firmer and more stable price levels for the major products, and reduced dependence on intervention buying in domestic policies. The former condition itself depends on the success of the agreement in increasing trade and reducing protection: Removing export subsidies may be the only way to create the conditions under which they are not needed. As for domestic programs, it is possible that practice and sentiment in the European Union may have moved further away from the use of market support policies to other instruments by the end of the negotiations. If these conditions were met, then a new set of negotiations could, say, set a target to phase out export subsidies over a sevenyear period.

Besides the question of export subsidies, several problems remain in the area of export competition. In the Uruguay Round, export credits were declared to be a form of export subsidy, but it did not prove possible to agree on constraints. Countries belonging to the Organization for Economic Cooperation and Development have negotiated a code for non-agricultural export credits, which puts limits on credit terms and the length of credit extension, but it has not been possible to include agriculture in this agreement. This leaves this topic as one to be

\footnotetext{
${ }^{18}$ Pakistan argues for the immediate elimination of "all kinds of export subsidies by the developed countries."

${ }^{19}$ The EU paper does not stake out a position on export subsidies, but merely notes that they will be on the agenda. The Commission, as "manager" of internal EU markets, would prefer not to have to use export subsidies, of course. But until internal prices are reduced to a level much closer to world prices, surplus products will need to be removed from the domestic market. Supply control is in place for sugar, cereals, and dairy production, but is not popular. One intriguing question is: What can other countries offer to the European Union in exchange for an agreement to eliminate export subsidies?
} 
dealt with in the next round, though some countries have indicated that they do not wish to "pay twice" for getting rid of such policies. ${ }^{20}$ It should be possible to agree on the allowable terms for such credit, and hence be able to calculate the magnitude of the subsidy that is involved if softer credit terms are offered. The best way to deal with the subsidy equivalent of such concessionary credit is to charge it against the export subsidy constraints in the schedules.

\section{Domestic Support}

It is one of the ironies of the Uruguay Round that, although the biggest conceptual breakthrough was the acceptance by countries that domestic policies were a legitimate concern of trade talks, the actual disciplines imposed on those policies through the reduction of the Aggregate Measure of Support (AMS) were rather weak. The key question for the next round, therefore, is whether to strengthen or abandon the attempt to constrain domestic policies. The fact that the AMS constraints have not been binding for the large majority of countries does not mean that the constraints on domestic support have been ineffective. The process of re-instrumentation of domestic support programs, away from those that most impede trade, has begun. The institution of the green box has in itself been useful in defining this objective. The attraction to countries of adopting green-box policies is both to guard against challenge from trading partners and to avoid being counted toward the AMS. Thus, the AMS constraint is of value even if not particularly onerous.

The slow but fundamental changes that are taking place in the agricultural policies of the major industrial countries need the encouragement and underpinning of international agreements. The changes in these policies have generally been in the direction of improving the climate for agricultural trade, in contrast to the policy changes in the 1960s and 1970s which led to more trade conflicts. The Uruguay Round was able to take advantage of these changes, such as the 1992 Reform of the EU's Common Agricultural Policy (CAP) and to get firm commitments on future policy directions and support levels. But this process of reform is still at an early stage and needs to continue in order to avoid a swing back toward the costly and ineffective policies of earlier times.

Some WTO members put weight on the reduction in domestic support through the AMS. The United States has called for an "ambitious target" to be set for the reduction of support. The Cairns Group points out that the "overall levels of support for agriculture remain far in excess of subsidies available to other industries." But, as with the United States, their target is clearly the trade-distorting (amber box) policies. Canada, however, indicates that it will seek "an overall limit on the amount of domestic support of all types (green, blue, and amber)." This could prove difficult. The European Union has announced that one of its objectives is to defend the blue box (in essence the compensation payments under the MacSharry and Agenda 2000 reforms) so as to avoid challenge to these policies and their scheduled reduction. ${ }^{21}$ It missed the chance of changing the nature of these payments to make them compatible with the green box criteria, though this could come at some stage in the negotiations.

The AMS constraints are acknowledged to be the least effective of the Uruguay Round bindings. But this does not mean either that they will not be useful in the future or that a continued reduction would not be appropriate. A continuation from the same base would be a relatively modest move, and yet even that will eventually result in 40 percent of the "coupled" domestic support having been removed or converted into less trade-distorting types of programs. But it would be even more effective to "catch up" with the reductions in import barriers and export subsidies. Thus one could envisage an agreed reduction of, say, 52 percent in the expenditure on price-related policies.

The "blue box" containing the U.S. and EU direct payments that were granted exemption from challenges under the Blair House Agreement was a creature of its time, necessary to get agreement to go ahead with the broader Uruguay Round package. It is, however, still a somewhat awkward bilateral deal not appreciated in other parts of the world. Such an anomaly could possibly be removed in the next round. The policies of the United States and the European Union themselves are changing for internal reasons. The U.S. Federal Agriculture Improvement

\footnotetext{
${ }^{20}$ See the paper by Uruguay (WT/GC/W/154). The URAA mandated negotiations to discipline export credits and guarantees. But whether this means that their regulation can be considered part of the UR package or not is doubtful. In practice, the outcome of such negotiations will be rolled into the agreements that come from the new round, particularly if linked to the removal of export subsidies and constraints on exporting by state trading enterprises.

${ }^{21}$ As in the case of export subsidies, EU authorities would not be averse to reducing direct payments over time. However, they have not yet found a politically acceptable formula for doing so.
} 
and Reform (FAIR) Act of 1996 goes further than ever before to make the payments to farmers decoupled from output and, therefore, compatible with the green box. The European Union has considered a similar move as a part of the continued reform started in 1992, as a way of making the CAP consistent with enlargement, but for now the idea has been shelved. ${ }^{22}$ The task for the new round will be made much easier if the European Union and United States have both modified their payments such that they meet the conditions laid down in the green box. The blue box could then be emptied and locked.

The green box presently contains a number of policy instruments that, while probably less trade distorting than price or income supports, still encourage an expansion of output. Sometimes they are related to otherwise reasonable programs such as crop insurance, but incidentally increase the incentive to produce by reducing risk. Other programs may be indirectly linked with production even though the main reason for payment is not output. This might be true of certain environmental payments, which could lead to an increase in output. But exporters fear that to re-open the definition of the green box might, however, allow countries to argue that it be expanded to include food security policies and non-decoupled support schemes designed to keep farming in certain areas.

This issue of the size of the green box appears to be where much of the pre-negotiation rhetoric is targeted. The argument is usually shrouded in terms of the "multifunctionality" of agriculture. The concept of multifunctionality is not in itself particularly novel, as agriculture has always played a complex role in rural societies, and rural areas have a vital place in national social and political life. But the European Union has latched onto the concept as a way of both providing cover in the WTO for policies that it would like to maintain and also providing a rationale for paying farmers in ways that are not tied to commodity output. Exporters are trying to neutralize any impact that the idea might have by pointing out that multifunctionality is neither restricted to Europe (though the EU Commission tends to link it to a European farming model, by implication different from the system of farming in competitor countries) nor indeed to agriculture. Importers are trying to link it to the "non-trade concerns" which are mentioned in Article 20 of the URAA as requiring consideration in planning the reform of the trade system.
The basic question remains: What does multifunctionality mean for trade policy? On the one hand, it could merely be a recognition that a variety of programs will be maintained in most societies which target specific aspects of rural life. For the trade system to be seen to rule out such programs would seem to be as risky as seeming to go against concerns of human health and animal welfare. On the other hand, if trade-restricting policies were to become the accepted instrument for maintaining multifunctionality, then that could signal a regression to the time of expensive commodity market distortions. The green box was intended precisely to deal with such rural concerns. It would be better to confirm the criteria for the green box and encourage multifunctional policies to conform rather than opening the green box up to be a repository for an assortment of production related payments.

One change in the constraints on domestic support that will probably be discussed is to make the AMS specific to individual commodities. This was the original intention in the Uruguay Round: It was at the Blair House negotiations between the United States and the European Union that the notion of aggregating the AMS over all commodities was introduced-essentially to weaken its impact. The AMS could thus be made more binding at a stroke by defining commodity specific amounts of "coupled" price support expenditures that could then be reduced over time.

\section{THE EXPANDED CORE AGENDA}

The core agenda is likely to be expanded by refinements and additions to the URAA. Three areas appear to be on the list for inclusion in this expanded agenda. These are issues that have been the concern of the Committee for Agriculture and the subject of papers in the Analysis and Information Exchange process. They include the way in which the TRQs in agriculture are administered, the activities of state trading enterprises (STEs), and the rules regarding export taxes and restrictions. Each of these items is closely related to the core, but each will probably require additional rules as

\footnotetext{
${ }^{22}$ The Agenda 2000 reform of the CAP, agreed to in March 1999, did not change the conditions for the direct payments to cereal farmers. Use of the land in program crops is still required. If new members are admitted under these conditions it is difficult to see how the European Union could avoid paying the direct payments to their farmers. This would constitute a large part of the budget cost of extending the CAP to new members.
} 
well as the continuation of cuts and the adjustment of schedules. But in each case the item is a part of a broader question that could be influenced by whether the agricultural talks are "stand alone" negotiations or a part of a larger package.

\section{Administering TRQs}

As a number of countries recognize in their position papers, the issue of developing a more uniform system for the administration of the TRQs is one of the most urgent tasks for the new agricultural round. TRQs for agricultural imports have created a new wave of governmental interference with trade through licensing procedures and provided a playground for rent-seeking traders - who will, in turn, have an incentive to lobby for the continuation of the high above-quota tariffs. The question is how to prevent the TRQs from interfering any more than necessary with the competitive development of trade.

One answer to the question lies in the method of allocation. In some cases allocation is done on a government to government basis, usually in accordance with historical market shares. But this perpetuates distortions in trade. To allocate the TRQs to the exporting country government, as is done for instance in the case of U.S. sugar imports, implies a deliberate attempt to influence the pattern of trade in favor of the recipient countries. ${ }^{23}$ This has been done in the past to target development aid or reward political friendship. ${ }^{24}$ Such non-market allocation schemes may have had their purpose. They do not, however, promote the competitive trade system that is the fundamental goal of the WTO. Efficient producers can make no headway against the assured market shares of the quota holders. Even allocating TRQs by country based on historical market shares does not ensure that the sourcing of supplies for the importer bears any necessary relation to the competitiveness of the supplier.

The simple solution to the efficiency problem is to allow quotas to be auctioned, as has been suggested in some academic circles. ${ }^{25}$ This would seem an economically sensible solution to the problem of the capture of rents and to counteract the incentives to keep the system in place. But this is also a reason why exporters in particular are likely to resist such a move. If the TRQs were auctioned to the exporter the impact would be much like a tariff. The exporter would bid up to the height of the tariff concession for the right to sell in the import market. The capture by the government of the rent through the auction process in effect turns the TRQ into a quasi-tariff, with the height discovered through the auction process. Where the TRQs replace previous access agreements in which the quota was allocated to the exporter, the result of the auction would be to reduce the return from selling into this market. Thus, there could be considerable resistance to the auctioning of TRQs.

The type of allocation mechanism that causes most problems, however, is that which gives the import rights to domestic concerns. Exporters feel they are neither getting assured access (as the agency or firm concerned can choose not to import the product, leading to underfill of quotas) or they are not gaining the benefit of the access (in essence not receiving any of the quota rent). In instances when the TRQs have a deliberate purpose, such as the EU arrangements with the African, Caribbean, and Pacific countries (ACP) and those of the Mediterranean Basin, capture of rents by the importing firms negates much of the benefit of the scheme. When competing domestic producers receive the import entitlements (as has happened in a few cases) then the market access inherent in the TRQs may be elusive.

Any allocation mechanism is subject to criticism. Using historical shares locks in trade, auctions tax the exporter for what is supposed to be market access, and allocation to import agencies encourages rentseeking. The best solution in the end may be to steadily

\footnotetext{
${ }^{23}$ The U.S. sugar import regime, involving the establishment of TRQs for traditional suppliers, was introduced in 1982, and thus predates the Uruguay Round. However, the quotas are now included in the WTO Schedule for the United States as part of its commitments made in the Uruguay Round. An argument might be made that the quota allocations were in any case likely to be distorting trade, as they took no account of changes in costs among suppliers. They were also of dubious consistency with GATT Article XIII, which endorses the use of market shares for the initial allocation of quotas but argues that they should be revised when changed circumstances render that allocation distorting

${ }^{24}$ Other examples that have caused trade friction include the EU allocation of TRQs for bananas, contributing to the WTO trade dispute, and the U.S. allocation of quotas for dairy products - to the benefit of the New Zealand Dairy Board. The recent WTO panel report in favor of Ecuador's claim that it should have received a larger share of the EU banana market has confirmed the interpretation of Article XIII that quotas should change to reflect cost and competitiveness among suppliers. The U.S. dairy quota allocation raised awareness in the United States of the significance of STEs other than the Canadian Wheat Board.

${ }^{25}$ Tangermann explores the arguments in favor of auctioning the TRQs (Tangermann, 1997). The issue of auctioning quotas was addressed some years ago by Bergsten and colleagues in the context of U.S. import policy. It is an interesting comment on the lack of economic rationality in trade policy - and the attraction of rents to trading interests - that such a simple device as auctioning quotas has not so far caught on with politicians and policy-makers (Bergsten, et al., 1987).
} 
increase the TRQs, as suggested above, or to reduce the rents by cutting above-quota tariffs, until the issue of how to allocate them is rendered moot.

\section{State Trading Enterprises}

There are three separable issues surrounding state trading. ${ }^{26}$ One is the question of whether state trading importers can reduce market access below the levels agreed in the schedules. The second question is whether exporter state traders can use "hidden" export subsidies to increase market share. The third issue is, in contrast to the suspicion of export subsidies, a fear that exporters with exclusive or special privileges can exploit consumers by using their monopoly power. The first two of these are largely agricultural issues, and will probably be subsumed in the agricultural talks. The third issue is more general, and should rightly be dealt with in the broader discussions on competition policy, a topic of a subsequent section in this paper.

The issue of state trading enterprises that have special or exclusive rights in import markets can be thought of as an extension of the problem of market access. Under WTO articles, state trading importers are not supposed to grant more protection than that given by the bound tariff (Article II:4, GATT 47). Countries could, however, go further than just ensuring that state trading importers do not give more protection than the bound tariff. It would be possible for instance to link the administration of the TRQs with the import operations of state traders, perhaps converting the TRQ into an obligation to import rather than an opportunity. This could reduce the suspicion that STEs might be responsible for the underfill of the quotas. At the other extreme, one could mandate that all (or a share) of the TRQ be marketed through private channels, thus providing some competition for the STE and allowing price and markup comparisons to be made.

The quantification of export subsidies and their reduction has left more visible the distinction between those countries where exports are privately sold from those where a parastatal controls such exports. There is widespread concern in those countries where trade is by private firms that the state trading enterprises can obtain cheap credit from their governments, offer better terms to buyers, and generally compete unfairly with the private trade. To the extent that these practices could be labeled as export subsidies, the issue is one of monitoring and transparency. But some commonly used devices such as price pooling (giving the producer an average price over several destinations or time periods) are also seen as giving the producer an unfair advantage. It might, therefore, be a matter for negotiation as to whether any constraints need be placed upon STEs with regard to their producer pricing policies.

The question of single-desk selling agencies for agricultural products is at the heart of this issue. On this there are some clear conflicts between the exporters. The United States has indicated that it would like to "strengthen rules ... disciplining activities of state trading enterprises." The Cairns Group (with Canada as a member) is tactfully silent on the issue, but Canada (in its "Initial Position" document) states unequivocally that it wishes to "maintain Canada's ability to choose how to market its products, including through orderly marketing systems such as supply management and the Canadian Wheat Board." It attempts to head off a confrontation with the United States by indicating that it will "not engage in sterile debates over alternative marketing philosophies," though it also indicates a willingness to "discuss any factual concerns" over "alleged trade effects of orderly marketing systems." Demonstrating that the best defense is often a good offense, Canada adds that it will "seek to ensure that any new disciplines proposed to deal with the perceived market power [of single-desk sellers] apply equally to all entities, public or private, with similar market power." What holds for the Canadian Wheat Board (CWB) must hold for Cargill as well! ${ }^{27}$

Different marketing practices among exporters are inevitable, and not in themselves undesirable. But international guidance is needed as to which practices of parastatal export agencies are consistent with agreed conditions of competition and which distort that competition. Now that the more clear-cut kinds of export subsidy have been identified and included in the country schedules of allowable subsidies, the main task of the negotiations will be to clarify the definition as regards the actions of state trading exporters. ${ }^{28}$ This would ensure that such actions as dual pricing and price

\footnotetext{
${ }^{26}$ For a more detailed discussion of this issue, see Josling (1998).

${ }^{27}$ Of course one can argue about the interpretation of "similar market power," but it remains true that many Canadian farmers claim that even if they were relieved of the obligation to sell to the CWB they would have to sell to one of a very few U.S. multinational corporations.

${ }^{28}$ In this regard the outcome of the dispute over Canadian dairy exports is useful. The panel report has indicated that the use of special export grades of milk, which can be sold at a lower price to processors for export of dairy products, constitutes a form of export subsidy under the URAA.
} 
pooling, if deemed to be hidden subsidies, could be counted against the schedule for that country.

\section{Export Restrictions}

In the next round, importers are likely to lead a movement to constrain the ability of exporters to restrict supplies. After all, restraints on exports are no less inconsistent with an open trade system than restraints on imports. Export taxes should be included under the same qualifications as quantitative restrictions. The argument has already surfaced in connection with the Food Security Declaration appended to the Uruguay Round Agreement (the Ministerial Decision on Measures Concerning the Possible Negative Effects of the Reform Program on Least-Developed and Net Food-Importing Developing Countries). It seems inconsistent to leave in place the possibility of export taxes and quantitative restrictions that have an immediate and harmful impact on developing country food importers.

The practice of export taxes and export restraints through quantitative controls can conveniently be thought of as an extension of the issue of export competition. Within the GATT, export controls are generally disallowed, though export taxes are deemed innocuous. Article XI of GATT 1947 prohibits quantitative export restrictions, but makes an explicit exception for "export prohibitions or restrictions temporarily applied to prevent or relieve critical shortages of foodstuffs or other products essential to the exporting contracting party." There is a clear conflict between the ability of exporters to withhold supplies to relieve domestic shortages and the reliability of the world market as a source of supplies for importers. The inclusion of stronger disciplines on export taxes and embargoes is likely to be part of the next round of agricultural talks.

Several countries have indicated their views on this matter. Canada indicates that it will seek a ban on "the inclusion of food and feedstuffs in national security embargoes" together with a ban on "export restrictions that would reduce the proportion of the total supply of an agricultural product permitted to be exported compared to the proportion prevailing in a previous representative period." Japan also argues for strengthening the disciplines concerning export taxes and export restrictions in part to "redress the balance of rights and obligations between exporting and importing countries." Developing countries have so far focused on other aspects of food security, such as putting "teeth" into the Ministerial Decision. The
EU paper does not mention export restrictions and taxes: It was the introduction of export levies in 1995 and 1996 to keep cereal prices from rising on the internal EU market that has reawakened interest in the issue of export restrictions.

\section{PARALLEL ISSUES FOR THE NEGOTIATIONS}

As if the core agenda and its extensions were not enough, negotiators will be faced with a set of "parallel" issues that could determine both the tone and even the content of the agricultural talks. These include the safety and environmental issues as well as those of trade preferences and regionalism. Agriculture is intimately involved in each area, though the main discussions will be outside the agricultural talks.

\section{Health, Safety, and Environmental Issues}

Among the most controversial issues that will confront negotiators is that of disparate health, safety, and environmental standards. Some of these issues have been around for a long time. Others are new and pose a challenge for the trade system as a result of their novelty. Some reflect increasing sensitivity of consumer and environmental groups to food-related issues. Others arise because firms find the different costs of compliance to have an impact on competitiveness.

Conflicts arising from different sanitary and phytosanitary (SPS) standards have posed problems for the GATT for many years. Under the GATT 1947 , sanitary and phytosanitary measures which impinged on trade were covered by Article XX(b), which allows countries to employ trade barriers "necessary to protect human, animal or plant life or health" that would otherwise be illegal-so long as "such measures are not applied in a manner that would constitute a means of arbitrary or unjustifiable discrimination between countries where the same conditions prevail, or as a disguised restriction on international trade" (Josling, Tangermann, and Warley, 1996). But Article XX had no teeth: There was no definition of the criteria by which to judge "necessity," and there was no specific procedure for settling disputes on such matters. The attempt in the Tokyo Round to improve on this situation through the Agreement on Technical Barriers to Trade (1979), known as the Standards Code, also failed. Though a dispute settlement mechanism was introduced and countries were 
encouraged to adopt international standards, relatively few countries signed the Code, and a number of basic issues were still unresolved.

Intensive negotiations in the Uruguay Round led eventually to a new SPS Agreement that tried to repair the faults of the existing code. This Agreement defined new criteria that had to be met when imposing regulations on imports more onerous than those agreed upon in international standards. These included scientific evidence that the measure was needed; assessment of the risks involved; and recognition of the equivalence of different ways of testing and sampling. In addition, the dispute settlement mechanism was considerably strengthened under the WTO to make it easier to obtain an outcome that could not be avoided by the losing party. ${ }^{29}$ The force of the SPS Agreement comes in part from the more precise conditions under which standards stricter than international norms can be justified and partly from the strengthened dispute settlement process within the WTO. In this regard, much was expected of the panel report in the beef-hormone dispute between the European Union on the one hand and Canada and the United States on the other. This was widely seen as a test case for the new SPS Agreement. ${ }^{30}$

The SPS Agreement was reviewed earlier this year by the SPS Committee, which found no reason to suggest modifications. The United States and the Cairns Group are not likely to wish to tamper with a hard-won agreement that has "science" at its core. The European Union, however, has let it be known that a few amendments would not be out of place. The desire to build in the reaction to consumer confidence is natural: Presumably it could be argued that the beef-hormone case would be rendered moot by a well-crafted clause written into a revised SPS Agreement. The question as to whether the trade system can tolerate regulations that take into account subjective or irrational consumer demand shifts is one of the most contentious issues in trade policy between the United States and the European Union.

One particularly contentious issue that is directly relevant to the global agri-food system is the extent to which the use of genetically modified organisms (GMOs) is harmful to the environment or indeed to consumer health. ${ }^{31}$ Concerns with transgenic crops, such as those with herbicide resistance built into their genetic make-up, have centered around the possibility of unpredictable crosses with wild species and, hence, the development of herbicide resistant weeds. Those with genetically-manipulated insect resistance give rise to concerns about the development of resistant insects and about collateral damage to harmless or beneficial insects. Clearly there needs to be vigilance to avoid the undesirable side effects of otherwise useful technology. Other fears are that consumers who suffer from plant-related allergies may react to the presence of genes from those plants to which they are allergic. The most commonly recommended remedy for preventing such problems is adequate labeling, but even this creates problems for public policy.

That the GMO issue will come up in the trade talks is inevitable. How it can be resolved, or at least channeled in a way that does not impede other areas of the talks is less certain. The United States has suggested that "additional approaches that address market access issues for biotechnology products" be pursued. Canada has suggested a Working Party to look at all aspects of the GMO issue, presumably including labeling and import restrictions, as a way of dealing with the issue directly. The European Union has positioned itself to take the view that existing agreements (such as the SPS and Technical Barriers to Trade (TBT) Agreements) may need to be revised in the light of the challenge of GMOs. The exporters have been trying to coordinate their positions through the Cairns Group and through bilateral talks. The Asia-Pacific Economic Cooperation (APEC) ministers have also been discussing the development of a coordinated plan for the regulation of trade in GMOs. The apparent aim at the moment is to isolate the European Union on this issue rather to engage it in a trade forum.

Creeping up behind GMOs as the next controversial issue is that of animal welfare. Few topics

\footnotetext{
${ }^{29}$ The Decision on the Application and Review of the Understanding on Rules and Procedures Governing the Settlement of Disputes (the Dispute Settlement Understanding) provides a framework for the better enforcement of panel rulings. To block the adoption of a Report from a Panel now requires consensus. Any party may appeal the ruling (on issues of law), but the Appellate Body Report is final.

${ }^{30}$ On July 31, 1981, the EC Council of Ministers adopted a Directive banning hormones in livestock production (81/602/EEC). This led, after a tortuous legislative journey, to the enactment of regulations on December 31, 1985, which banned the use of all of the hormones for growth promotion purposes and established regulations for the use of these hormones for therapeutic purposes. This Directive was challenged in the European Court of Justice, and was annulled by the Court on procedural grounds. Finally, the Directives were reintroduced by the EC Commission and readopted by the EC Council as Council Directive 88/146/EEC on March 16, 1988.

${ }^{31}$ For a full discussion of this topic, see Nelson, et al. (1999). The trade policy implications are elaborated in IPC (1998a).
} 
engender public outrage, at least in Northern Europe, and pose more serious problems for international regulation. Farmers in Europe are already having to modify their farming practices to meet new animal welfare standards. They are naturally arguing that it would be "unfair" to leave them to compete with producers who do not have to meet the same standards. The issue will revolve around whether some degree of protection at the border is allowable to compensate for the extra costs, whether border controls can keep out goods produced under conditions considered unsuitable by the importing country, and whether direct assistance can be given to domestic farmers who are burdened by such regulations without such assistance being considered "yellow-box" support. In this respect, the animal welfare debate may become part of the discussion on environmental programs, where the same choices apply. But the animal welfare issue could also take on some of the aspects of the GMO controversy, if genetically modified animal products start to be marketed.

\section{The Trade Preference Issue}

Trade preferences have a long history in agriculture. Countries in Europe (particularly France, the United Kingdom, and the Netherlands) have kept close commercial ties with their former colonies based on preferential access to their markets. These ties were assumed by the European Union under successive Lomé Conventions, the current one of which expired in March 1999. The European Union suggested significant changes in the agreement, in part to try to avoid the perpetuation of a dependency relationship based on the export of a small number of commodities with limited market prospects. The Lomé Convention is in any case likely to change markedly in the coming years: It has been declared to be in contravention of international trade rules. ${ }^{32}$ The European Union was granted a waiver until the year 2000 from the obligation to bring the Lomé Convention into conformity with the WTO rules. If such a waiver is still required after that year, it will have to be renewed annually. ${ }^{33}$

Developing countries face a dilemma in the area of trade preferences. On the one hand, many developing countries benefit from them. On the other hand, most of them grant preferences at the expense of other developing countries. Exporters under the schemes gain valuable access and higher prices, but get locked into particular markets and products. Those exporters that have not had extensive preferences have in many cases outperformed those that have had such access. Moreover, preferences that are given unilaterally by the importer do not have the same guarantees as trade access under the WTO. Investors may remain wary of the future of some of the commodity preference schemes.

Illustrative of the preference issue is the conflict over trade in bananas. A WTO panel found that several of the mechanisms used to allocate banana imports under the EU's regime of quantitative restrictions violated international trade rules. The dispute has put banana-exporting countries at odds with each other and led to the (mistaken) view that the WTO is being used to undermine the economies of the smaller islands that are heavily dependent on the crop for export earnings. The banana issue is the most contentious trade policy issue for the Caribbean and Central American regions.

The European Union has promised a new set of regulations that should prove to be more WTOconsistent. The urgency is that an unresolved banana issue will be a problem for the European Union as it enters into negotiations with its WTO partners. The European Union will, if the beef-hormone dispute is not rapidly settled, be saddled with the burden of two adverse rulings by panels with which it has not yet complied. But the solution of the banana problem itself could eventually be settled in the negotiations, just as the long-running oilseed dispute was settled in a package (at Blair House) along with the final agreement on agriculture in the Uruguay Round.

\footnotetext{
${ }^{32}$ The first banana panel raised the issue of the legality of the Convention under the GATT. The Convention could hardly be justified as a part of a Free Trade Area, under Article XXIV of the GATT, as it was non-recip rocal. ACP countries did not have to grant duty-free access to the products of Europe. Preferences are also allowed under the so-called "enabling clause" for giving advantages to developing countries. But the justification of the Lomé Convention as a manifestation of "special and differential treatment" in favor of developing countries, encouraged by the GATT, was rendered doubtful by the fact that many developing countries (in Asia, mostly) did not qualify for ACP assistance and trade benefits.

${ }^{33}$ The European Union is not the only body to grant trade preferences. The United States runs regional preferences for Central America and the Caribbean under the Caribbean Basin Initiative and other schemes. Though these cover more products than the EU protocols, they are also not WTO-compatible Free Trade Areas nor non-discriminatory development assistance. They also have required a WTO waiver, and will eventually become reciprocal free-trade schemes.
} 


\section{The Challenge of Regionalism}

The most significant challenge to the WTO comes from the success of a parallel means of trade liberalization - that within regional trade pacts. The recent growth of regionalism, unlike many of the earlier regional trade pacts, has significant implications for agriculture. Many regional trade agreements have in the past left agriculture out of the free-trade provisions, in deference to the political sensitivity of the sector and the potential conflict with domestic policy objectives. The situation is rapidly changing. Numerous regional trade pacts - the North American Free Trade Agreement (NAFTA), the common market among Argentina, Paraguay, Uruguay, and Brazil (MERCOSUR), the Andean Pact, the Caribbean Community and Common Market (CARICOM), and the Closer Economic Relations (CER) Agreement between Australia and New Zealand-all include agriculture in their free-trade provisions. The countries of Central Europe have included agriculture fully in the Baltic Free Trade Area (BFTA) and in a more limited way in the Central European Free Trade Area (CEFTA). The Europe Agreements that aim for free trade between the Central and Eastern European countries and the European Union also include agriculture, albeit with some temporary quantitative limits. In Asia the process has gone less far: The countries of the Association of South East Asian Nations (ASEAN) have been unwilling to incorporate agriculture as an integral part of their free trade area (AFTA), though some commodities are included. To the extent that these agreements do include agriculture, this gives them a new significance in the process of liberalizing agricultural trade and necessitates some coordination with the multilateral process.

The fact that the new brand of regional trade agreement includes agricultural trade within the bloc is clearly a mixed blessing. It carries with it the danger that high-cost production will be sheltered and supported in these trade blocs, as Europe's regime of free trade within the European Union has done. But this arose because of the high level of support and protection at the border. Today's new regional blocs seem to have learned the lesson. In other blocs, trade creation seems to have been the dominant effect, helped in large part by the domestic policy reforms that have gone hand-in-hand with the regional trade pacts. Freer regional trade in agricultural products seems, therefore, in most cases to be consistent with, and hence a step towards, global trade liberalization. The only major qualification is that each member of a regional trade agreement should reduce tariffs on third-country agricultural trade so as not to increase regional preferences and hence generate trade diversion. This could either be done jointly through agreement with other members on external protection, in the case of a customs union, or independently through unilateral liberalization, in the case of a free trade area. Multilateral negotiations become the best way to keep down the level of protection against non-partner imports so as to avoid trade diversion. If both internal and external protection are progressively removed, the regional and the multilateral paths in effect go hand-in-hand toward the same goal.

The potential conflicts between regional and multilateral trade agreements urgently need to be resolved. In the case of agriculture, the next WTO round should integrate global and regional liberalization processes. This could be done by establishing targets for multilateral agricultural trade liberalization that are consistent with those already announced within the regional and supra-regional groups. Negotiations could even be facilitated by the adoption of collective positions by regional blocs. The multilateral talks could incorporate supra-regional negotiations as ways of achieving the global targets and focus on the relationship among such groups and between those groups and outside countries.

Three possible ways could be explored to strengthen the complementarity between regional and global trade rules. Each of these steps supports the multilateral system without provoking a direct clash with the forces that are working for regional trade integration. ${ }^{34}$ First, the existing WTO rules on the acceptability of free-trade areas and customs unions could be applied more rigorously. The requirement that "substantially all trade" be covered should be clarified. Omitting a major sector of the economy such as agriculture should not be possible, and even omitting a handful of sensitive commodities should only be allowed if the existing (and potential) trade in those products is negligible. Moreover, the rule could be further strengthened by agreeing that the exemption is of a temporary nature, and that in time all trade would be covered.

Second, as a condition of the free-trade area or customs union being accepted by other WTO members, the countries participating should be required to ensure that other countries are not adversely

\footnotetext{
${ }^{34}$ For an elaboration of these arguments, see Josling (1998) and IPC (1998b).
} 
affected. This should be done primarily through reductions in the tariff levels against third countries. Presently, countries can ask for compensation if tariffs go up, but the most common cause of trade diversion arises from a switch in suppliers that can take place even if no tariffs increase. It would be useful to require reduction in applied tariffs when regional trade blocs are set up or expanded.

The third step that could usefully be taken at the multilateral level is to ask the Committee on Agriculture, in conjunction with the committee that oversees free trade areas and customs unions, to report on the activities of these blocs in light of the multilateral trade reform process. Such reporting could include monitoring of trade flows and preference levels, as well as policy changes that have significance for the multilateral system. Circumstances where a conflict between regional and global liberalization and trade reform is likely could be identified and discussed. Trade blocs would in this way be obliged to defend their actions in the light of the application of global rules and objectives. Other countries would have an opportunity to question such developments rather than relying exclusively on the dispute settlement process to challenge cases of conflicts. Such additional ongoing scrutiny would greatly improve understanding about the magnitude of the conflict between regional and multilateral trade processes and rules in agriculture.

\section{RELATED ISSUES}

Even further removed from the realm of agricultural trade negotiations, but in many ways as relevant for the sector, are three additional issues that might become a part of the next round. One is the regulations surrounding intellectual property. As a result of the spread of biotechnology, agriculture now has a stake in this regulatory process. Foreign investment is also increasingly important to the agricultural sector, and that again could be on the agenda for the round. Finally, the large and complex issue of competition, already mentioned above in connection with the activities of state trading enterprises, could be a subject for at least initial discussion.

\section{Intellectual Property Issues in Agriculture}

Among the newer aspects of international trade policy is the setting up of rules regarding intellectual property. The emergence of international rules predates the GATT Uruguay Round, with the establishment of the World Intellectual Property Organization (WIPO), but there was insufficient incentive for countries without intellectual property protection to join. But the breakthrough came in the Uruguay Round when the negotiating countries signed the Trade Related Intellectual Property (TRIPS) agreement. TRIPS brought a degree of harmonization to the disparate treatment of patents, copyrights, and trademarks in various trading countries.

One important area of the food and agricultural sector where the rules on intellectual property are significant is in the input industries. The seed sector, in particular, has already made use of such international values to try to reclaim some revenue from farmers. The ability to patent plant varieties has been a controversial topic for some years. Now one has the possibility to patent particular manipulations of genetic material such as is at the root of biotechnology. This would give a much greater chance for companies to license new varieties to others to plant. ${ }^{35}$ This is of concern among some who fear that the highly concentrated seed industry could extract considerable profits from farmers worldwide, as they would have to pay from season to season for planting even their own retained seed.

A second linkage between agriculture and intellectual property is in the area of geographical trademarks and appellations. It is widely held that such geographical labels help the consumer to pick a brand on which they can rely. It is also possible that the same useful information can have the effect of inhibiting competition and earning scarcity rents for the holder of the patent. But, regardless of the merits of particular systems of labeling, some form of brand identification is an important part of the trade system in foods as in other areas. The European Union is particularly keen to see an extension of the protection for geographical appellations (it does not wish to consider them as mere trademarks) as a reflection of the commercially important name recognition of many European food specialties. In any package of measures, some further protection of this type could have a useful role as an issue that the European Union can sell to its domestic constituents.

\footnotetext{
${ }^{35}$ Though plant breeders' rights have been recognized since the 1930s in the United States, it has proved impossible to patent improvements that come through selection in the field (landrace crosses) and not easy to see the justification for doing so. But when the improvement comes in the laboratory, as a result of using particular genetic material in a biotech process, the case for restricting unlicensed use increases.
} 


\section{Foreign Investment and Agriculture}

The global system, whether in agri-food products or in automobiles or computers, depends on foreign investment. But global investment also requires rules, and these are not yet fully developed. Several issues are at stake in the area of investment: Assurance of the host country authorities that the assets owned by foreigners will not be expropriated, that earnings from investments can be taken out of the country, and that there will not be undue restrictions (such as requirements to use domestic inputs or to export a share of outputs) on the foreign operation. Firms have alternatives, and countries that maintain policies that are not investment-friendly may lose the opportunity to participate in the global division of labor. The global reach of food retailing and processing similarly requires the assurance that facilities abroad will not be expropriated and that undue restrictions are not placed on the repatriation of earnings.

Some start to the forging of a more transparent investment environment was made in the Uruguay Round, with the Agreement on Trade Related Investment Measures. More recently, the Organization for Economic Cooperation and Development (OECD) countries have been trying to work out a Multilateral Agreement on Investment (MAI). At present the MAI is moribund, a victim in part of unfavorable reactions from the non-OECD countries. But the European Union has promised to raise the issue again for inclusion in the next round of trade talks. Developing countries are generally wary of negotiating on a topic where they consider that they have little to gain and something (at least in policy flexibility) to lose. Agricultural issues have not been prominent in the investment rule debate, but the outcome of these negotiations will clearly have an impact on the agri-food sector.

\section{Competition Policy}

The third and more profound set of related issues is the need for international rules on competition policy. It could be argued that a global trade system needs global competition laws, but this argument has had little effect so far on trade policy discussions. Whilst some are calling for full-scale negotiations on international competition policy, others maintain that the most one can do is to make sure that each trading country has its own antitrust policy in place. But the minimalist approach is unlikely to be satisfactory as a long-term solution by itself. The best policy for curbing misuse of market power in any one country is an open trade system. But the very openness of the trade system allows large firms to develop market power in the world market. Global competition policy will eventually focus more on market power in world markets than on enforcing competition policy in each national market.

The issue of competition is at the heart of the conflict over state trading. Without market power the state trader can do little. ${ }^{36}$ If markets are contestable, the agency that imports cannot sell for more on the domestic market than a private trader who buys at world prices and pays a tariff. An export STE can only buy products to sell abroad if it pays the same price that private traders would pay. It has no incentive to sell below world prices, other than to remove inventories or to develop markets: In this respect it acts the same as a private firm. It is the ability to block other imports or to act as the exclusive sales agent for farmers that sets parastatals apart from other marketing agencies. But it is difficult to see how one can develop effective disciplines on competition among agricultural enterprises without tackling the problem across all sectors.

Parastatal agencies in agriculture are, of course, only one set of institutions that might eventually fall under the watchful eye of the WTO. Concentration of economic power is not confined to public agencies given monopoly rights in importing or exporting. Private firms can have significant market power to influence prices. Should there be any rules relating to the use of market power in international markets? What are the dangers that the rules are trying to prevent? Is the problem the withholding of supplies to raise the price of commodities? This seems relatively unlikely in the case of basic foods, but could happen with vital supply components. Or is the problem one of dumping and market disruption? The incorporation of antidumping rules in a set of more comprehensive competition regulations is the object of many trade economists. Whatever is agreed upon will have significant implications for global agriculture.

\section{OTHER INFLUENCES ON THE AGENDA}

Some of the most important items are not even on the agenda. One of these is the question of

\footnotetext{
${ }^{36}$ The relationship between market power and STEs is emphasized in MacLaren and Josling (1999).
} 
China's membership, which was still under negotiation at the time of the Seattle Ministerial. A somewhat different issue is the debate that is continuing in many quarters on the costs and benefits of globalization. The round will act as a focus for those who are discontented with the process of liberalization and its role in promoting global markets. Trade officials are taking seriously the need to engage the public in an attempt to convince domestic constituencies of the value of continuing the process. Agriculture and food issues promise to have a prominent place in this debate. Finally, the exogenous forces of weather, crop failure, and other market perturbations will also play a role, though in what way is not entirely clear.

\section{Expanding Membership of the WTO}

The application of China for re-entry into the WTO (it withdrew from GATT membership in 1950) poses very significant problems and enormous possibilities for agricultural trade, as for many other aspects of the international trade system. The opportunities are the result of the huge market potential and the strong economic growth. China could undoubtedly become a major player in agricultural markets: The issue is under what conditions and rules will such trade take place? Besides issues of market access, Chinese accession raises fundamental systemic questions such as the behavior of the state trading entities in China and indeed the extent to which the government controls, albeit indirectly, all trade decisions in that country. As a major player in agricultural trade markets, the terms under which China should be allowed into the WTO will have a significant impact on the rules that can be set for other countries with parastatal agencies active in the market.

The conclusion in 1999 of bilateral talks between China and the United States has given new hope that accession will soon be a reality. Elements within the Chinese government that are favorably inclined to the continued opening up of the economy have apparently prevailed, and presented a package that offered major concessions to the demands of the United States. Following talks with the European Union, this agreement could provide the basis for membership by some time in the year 2000. The generally liberal thrust of the Chinese offer could be of significance in the agricultural talks. China is reported to have agreed not to use export subsidies. Domestic support levels are also to be bound at low levels. Tariffs of a modest level will leave that country far more open than any of the other Asian importing nations, and almost as low as the most liberal members of the Cairns Group. This could have an impact on the talks. The prospect of a large open market in China is likely to encourage other countries to gear their agricultural policy toward exports.

Russia has also requested to join the WTO, along with the Ukraine and several other parts of the former Soviet Union. The problems that will emerge when these negotiations get under way will have some of the same features as the talks with China. Other countries will be concerned with the role of the state and the extent to which exports can be subsidized or imports restricted by nontransparent state action. However, some of these countries have made major political reforms that make them "open" and less likely to cause fundamental conflict with WTO rules. For these, one might anticipate somewhat more speedy negotiations than have been the case with China. They could even enter the WTO within the next year or two. But this is not true in the case of Russia. Until such time as that country develops a stable administrative system capable of implementing WTO rules and obligations, it may have to be content with "observer" status.

\section{The Politics of Globalization}

The globalization of the food and agricultural sectors that has taken place over the past two decades has changed the relationship between trade policy and the agricultural sector in critical ways. Among these is the fact that agriculture has been caught up in the politics of globalization. Nowhere is that more clearly seen than in the area of health, safety, and environmental standards. The political setting in which discussions of the SPS Agreement will take place, both with respect to the impact of globalization and with regard to the role of developing countries, could in part determine the future of the agreement. The WTO Council will be under pressure from nongovernmental organizations to address the impact of globalization on the environment, income distribution, and national sovereignty. One aspect of this pressure will be related to food safety. The politics of food safety has been transformed by a chain of events that has sensitized public interest groups, particularly in Europe, to the question of the reliability of the food 
system. Starting with problems arising from the misuse of hormones in animal feed in Europe in the 1970 s, through adulterated wine and vegetable oil in the 1980s, to the bovine spongiform encephalopathy outbreak ("mad cow" disease) and the dioxin scare of the 1990s, a series of unfortunate health problems has convinced consumers and consumer watchdog groups that the regulatory systems are not always adequate. In addition, scientific bodies have also lost credibility in some countries in part as a result of evolving knowledge about the health effects of certain chemicals. Most important, politicians have become discredited as a source of assurance. Transferring responsibility to the international level does not seem to have helped establish credibility. There is a widespread public perception that international rules are imposing lower standards on countries through insistence on science-based risk assessment. ${ }^{37}$

What does this mean for international trade policy? Though there is little evidence that increased international trade in agricultural goods and foodstuffs has had any deleterious impact on food safety, the tendency is always present to make the link between importing food products from overseas and more lax health and environmental standards. As a consequence, food scares often have more than a proportional impact on trade. Export interests are unlikely to be sympathetic to the "irrational" views of foreign consumers, who, exporters believe, should learn to trust the authorities, even though their own consumers can be equally unpredictable. Exporting governments support this rational view, in particular since they don't have to face elections in the importing countries. From the standpoint of the politics of globalization, this plays into the hands of those who paint multinational companies as insensitive and mercenary. Thus at the Seattle meeting, where another act in the drama will be played out, governments are going to have to show enough concern about food safety to avoid losing the initiative to those who will use food scares to convince the public that global food systems are stacked against the consumer interest.

\section{World Market Conditions and Trade Talks}

One of the intriguing questions about trade liberalization in agriculture is the relationship between trade talks and world market conditions. On the one hand, it was clear from the experience of the mid-1980s that a period of low commodity prices concentrated the attention of agricultural politicians and brought the financial departments of governments to the view that they had to reform farm policies. The export subsidy war was becoming too expensive. But the pressure was off by 1990, as prices recovered. Reform succeeded in the mid-1990s in part because world prices were firm, and farmers felt they could live without the safety net of government purchases. ${ }^{38}$ But commodity prices tumbled again in 1998 and no immediate sign of recovery is at hand. The United States launched a financial rescue package in 1998 and followed it up with more relief in 1999. These emergency packages, whether or not strictly in the "green box" have certainly been in response to low prices, and thus must have some effect of keeping up production. It will be less easy for the United States to argue that its policy is now fully decoupled from prices and hence is productionneutral. On the other hand, the low prices have threatened a further budget crisis in the European Union, in particular in the face of its imminent enlargement, and made yet another CAP reform package likely in the next three years.

The interests of developing countries might also seem to be tied to world price movements. At times of high prices, food importers look for reliable food supplies both on commercial and concessional terms. In the 1970s, this translated into a focus on international agreements, food aid, and storage programs. Trade liberalization was delayed as countries geared up for shortages. But developing countries would also seem to be reluctant to liberalize when world prices are low, as in the mid1980 s, because domestic producers fear international competition. Some liberalization is possible at times of rapid currency devaluation during a period of adequate world supplies. Conversely, it may be most difficult to reform policies when world prices are firm. No one knows for sure how world prices will develop over the course of the next round, but economic recovery in Asia, together with any crop shortages, could provide a positive backdrop for the conclusion of the next set of agricultural negotiations.

\footnotetext{
${ }^{37}$ It is arguable whether environmental groups really fear a "race to the bottom" or merely a loss of influence as decisions are removed from local and national control to the international arena, where the multinational firms may be presumed to have more influence.

${ }^{38}$ Farmers in both the United States and the European Union did rather well out of reform, gaining initially from the compensation payments at a time when world prices were high (see Orden, Paarlberg, and Roe, 1999).
} 


\section{THE TIMING OF THE NEGOTIATIONS}

There are a few fixed points that give an indication as to the timing of the agricultural talks. The URAA itself mandated negotiations on agriculture to be started before the end of the transition period, i.e., in 1999. But starting the talks does not mean that they will move fast or far without further incentives or deadlines. It would be useful to get the talks off to a fast start, as soon as negotiating authority is received by the major actors, but there will always be elections or market developments that make it a bad time for some country or other to agree to liberalization. One of the few deadlines is 2003, when the Peace Clause expires. Thereafter, unless the Peace Clause is renewed, the general WTO rules governing subsidies and dumping will apply to agriculture. This will presumably give a useful boost to negotiations if they are not complete by that date. The promise to renew the Peace Clause may also be a useful incentive for countries such as the European Union to continue reforms.

Adding to the factors that might delay completion of the Round is the increased number of countries that will be taking part. Moreover, China and other aspirants (though not Russia) could also be members either near the start of negotiations or before they conclude. This will bring in important agricultural traders who will have considerable influence on world market conditions, but it may make reaching a solution more difficult.

Any WTO action has to be acceptable to all its members. In the past the leadership has fallen to the developed countries, and more particularly the United States and the European Union. This is rapidly changing. In particular, developing countries will play a more important role in the next round. This is clearly appropriate: They should be full partners in the continuation of agricultural trade reform. As major producers and traders of agricultural products, they need to feel that they are beneficiaries of this reform. But, in addition, these countries must also participate more actively in the market opening by bringing down the high ceiling bindings and giving up the remaining non-tariff trade barriers. This would also involve assurances by developed countries to resist policies that cause market disruption and threats to food security. Preferential schemes for commodity exports also need to be consolidated within regular trade agreements and differential treatment rules revised to encourage full participation in trade liberalization as soon as possible. The next round may focus as much on the integration of developing countries fully into the trade system as on the more traditional conflicts among industrial countries.

Does this mean that there will be little incentive to finish the negotiations once they have started? The United States in particular is concerned that the incentives to delay are removed. Hence, the proposal supported both by the United States and the European Union is for a time limit of three years. This conveniently coincides with both the expiry of the Peace Clause and the end of the current U.S. Farm Bill, as well as the date that the European Union has set for a review of some of its own measures.

Perhaps the main determinant of the timing and ambitiousness of the agricultural talks, however, is the decision as to whether they should be a part of a large, multi-sector negotiation or whether they will be self-contained. Most commentators argue that a negotiation that only included agriculture would be difficult to conclude. Countries that felt they stood to lose would have no offsetting gains in other areas. However, no agreement has yet been reached on the scope for the next round, and so it is uncertain what "package" will be possible.

\section{POST-SEATTLE POSTSCRIPT}

The WTO Ministerial that was intended to launch a new round of trade negotiations took place in Seattle amid confusion, both within and outside the meeting room. The Ministers assembled without an agreed draft document from their WTO Ambassadors in Geneva. In many cases, they also lacked the agreement of their governments to compromise to deliver a new comprehensive round. The time proved too short to bridge the fundamental gaps that remained between the various positions, and the difficulty of reaching agreement by consensus among a group of 135 nations was overwhelming. In the end the meeting ended with no clear decision taken either on the agenda for a new round or, indeed, on the next steps toward such a round. The prevailing wisdom is that it is unlikely that much progress will be made before the U.S. election at the end of the year 2000.

Outside the meeting rooms the degree of organization was better, though there was ample confusion both on means and ends among the protesters. Though the protests themselves played little role in the failure of the Ministerial, the political fallout from the intensity of the opposition to the WTO could be considerable. It will certainly be harder 
for the U.S. Congress to agree to the permanent granting of most favored nation status to China, a move that would seem necessary if that country is to join the WTO. And the legitimacy of the WTO dispute settlement process could also be undermined if it was to be directly challenged by national politicians in the name of "democracy."

The collapse of the Seattle talks, while disappointing, does not imply that the agricultural negotiations will not go ahead. As a part of the builtin agenda from the Uruguay Round, negotiations will begin in Geneva soon. The problem is that without the impetus that would have been given to the sectoral talks in agriculture and services, these two sets of discussions will have to advance through their own internal logic and political will. In the case of agriculture, this gives back control over the ambitiousness of the agenda to the reluctant liberalizers, such as Japan and the European Union.

A clear indication of this impact emerged from the dust of Seattle. The European Union was on the brink of agreeing to wording in the agricultural paragraphs of the declaration that would have excluded the term "multifunctionality" from the draft, and would have stated that the objective of the negotiations was to move "in the direction" of removing export subsidies. But, the European Union made it clear after the breakdown of the talks that these concessions would have to be negotiated afresh if the rest of the package was not agreed. The United States was suspicious that the European Union was pushing a broad agenda to avoid the spotlight falling on agriculture. The European Union, on the other hand, undoubtedly could have moved more easily on agriculture if other sectors had been included. The impact of single sector negotiations not embedded in a round, therefore, is to put the focus squarely on agriculture but also to make it more difficult to get a "good" outcome.

The Peace Clause, as indicated above, is the "internal" driving force behind further agricultural trade reform. But the impact of removal of the protection of the Peace Clause depends crucially on the effectiveness of the dispute settlement process. If countries lose their confidence in this aspect of the WTO, as the demonstrators on the streets of Seattle have clearly done, then the threat of action through panels is greatly diminished. This then could be the ultimate impact of Seattle. The agenda for further talks may well be curtailed, but progress could still occur. But the loss of political legitimacy and support for the WTO as an institution, and in particular a weakening of the dispute-settlement mechanism, would be a much more fundamental blow. How WTO member governments tackle the problem of mending fences and improving procedures in the next few months could well be crucial for agricultural as for other trade.

\section{REFERENCES}

Bergsten, C. Fred, Kimberly Ann Elliott, Jeffrey J. Schott, and Wendy E. Takacs. "Auction Quotas and United States Trade Policy,” Institute for International Economics, Policy Analyses Series 19, September 1987.

International Agricultural Trade Research Consortium. "Implementation of the Uruguay Round Agreement on Agriculture and Issues for the Next Round of Agricultural Negotiations," IATRC Commissioned Paper 12, October 1997.

International Policy Council on Agriculture, Food and Trade. "Plant Biotechnology and Global Food Production: Trade Implications,” IPC Position Paper No.7, 1998a.

"The Role of Regionalism in Agricultural Trade Reform,” IPC Position Paper No. 5, 1998b.

Josling, Timothy. Agricultural Trade Policy: Completing the Reform, Institute for International Economics, Washington D.C., 1998.

, and Allan Rae. "Multilateral Approaches to Market Access Negotiations in Agriculture," Paper prepared for the World Bank Conference on Developing Countries and the New Agricultural Negotiations, Geneva, October 1-2, 1999.

Stefan Tangermann, and Thorald K. Warley.

Agriculture in the GATT, St. Martin's Press, 1996.

MacLaren, Donald, and Tim Josling. "Competition Policy and International Agricultural Trade," International Agricultural Trade Research Consortium Working Paper, No. 99-7, 1999

Nelson, Gerald, Timothy Josling, David Bullock, Laurien Unnevehr, Mark Rosengrant, and Lowell Hill. "The Economics and Politics of Genetically Modified Organisms in Agriculture," University of Illinois-Urbana Champaign Experiment Station Bulletin No. 809, November 1999.

Orden, David, Robert Paarlberg, and Terry Roe. Policy Reform in American Agriculture: Analysis and Prognosis, University of Chicago Press, 1999.

Tangermann, Stefan. "A Developed Country Perspective of the Agenda for the Next WTO Round of Agricultural Trade Negotiations," Paper presented at a seminar in the Institute of Graduate Studies, Geneva, March 3, 1997.

World Trade Organization. The Results of the Uruguay Round of Multilateral Trade Negotiations, June 1995. 
RE V I E W

72 JULY/AUGUST 2000 